\title{
The effect of concentrate feeding amount and feeding strategy on milk production, dry matter intake, and energy partitioning of autumn-calving Holstein-Friesian cows
}

\author{
D. C. Lawrence, ${ }^{*} \dagger$ M. O’Donovan, ${ }^{*}$ T. M. Boland,† E. Lewis, ${ }^{*}$ and E. Kennedy* \\ ${ }^{*}$ Teagasc, Animal \& Grassland Research and Innovation Centre, Moorepark, Fermoy, Co. Cork, Ireland \\ †School of Agriculture and Food Science, University College Dublin, Belfield, Dublin 4, Ireland
}

\begin{abstract}
The objective of this study was to compare the milk production, dry matter intake, and energy partitioning of autumn-calving Holstein-Friesian cows offered a high or low amount of concentrate using 1 of 2 feeding strategies. One hundred and eight autumn-calving HolsteinFriesian cows were blocked based on milk production data from wk 3 and 4 of lactation, and were divided into low-, medium-, and high-milk yield subgroups. Cows were randomly assigned to 1 of 4 treatments $(\mathrm{n}=$ 27 ) in a $2 \times 2$ factorial design. Treatment factors were concentrate feeding amount, high concentrate $=7.0$ (Hi) or low concentrate $=4.0 \mathrm{~kg}$ of $\mathrm{DM} /$ cow per day (Lo), and concentrate feeding strategy, flat rate (FR) or group-fed to yield (GFY). In the GFY treatments, cows were allocated concentrate based on their milk yield in the third and fourth weeks of lactation. The lowestyielding cows $(\mathrm{n}=9)$ received 5.3 and $2.3 \mathrm{~kg}$ of $\mathrm{DM}$ of concentrate on the $\mathrm{Hi}$ and Lo treatments respectively, the highest-yielding cows $(\mathrm{n}=9)$ received 8.7 and 5.7 $\mathrm{kg}$ of DM of concentrate on the Hi and Lo treatments respectively, and the average yield cows received the same amount of concentrate as the corresponding FR group (i.e., 7.0 and $4.0 \mathrm{~kg}$ of DM of concentrate on the $\mathrm{Hi}$ and Lo treatments, respectively). The proportion of forage in the diet was $63 \%$ of total dry matter intake (TDMI) for the Hi treatment and $75 \%$ of TDMI for the Lo treatment. No significant interaction was noted between concentrate feeding amount and concentrate feeding strategy for dry matter intake or milk yield. Cows on the Hi treatment had a higher TDMI (18.7 \pm $0.36 \mathrm{~kg} /$ cow per day) compared with cows on the Lo treatment $(15.8 \pm 0.36 \mathrm{~kg} / \mathrm{cow}$ per day $)$. The milk yield of cows offered the Hi treatment was $1.3 \mathrm{~kg} / \mathrm{cow}$ per day higher than the milk yield of cows on the Lo treatment $(23.8 \pm 0.31 \mathrm{~kg} /$ cow per day $)$. Milk solids yield was 0.10 $\mathrm{kg} /$ cow per day higher on the Hi treatment than on the
\end{abstract}

Received January 6, 2014.

Accepted October 2, 2014.

${ }^{1}$ Corresponding author: Emer.Kennedy@teagasc.ie
Lo treatment $(1.83 \pm 0.03 \mathrm{~kg}$ of $\mathrm{DM} /$ cow per day). Cows on the Hi treatment had an estimated net energy demand of $18.0 \pm 0.38$ UFL (unité fourragère lait)/cow per day and a net energy intake of $17.6 \pm 0.33$ UFL/ cow per day during the experimental period. Cows on the Lo treatment had an energy demand of $16.8 \pm 0.38$ $\mathrm{UFL} /$ cow per day and an energy intake of $14.9 \pm 0.33$ UFL/cow per day. No significant difference in TDMI, milk yield, milk solids yield, or energy balance was observed between the FR and GFY treatments. By increasing the total amount of concentrate offered, cows had higher TDMI and energy intake, which resulted in increased milk production and reduced negative energy balance and body condition score loss.

Key words: variable feeding, concentrate, feed to yield, energy balance

\section{INTRODUCTION}

In Ireland, winter milk production relies on high inputs of ensiled forage and concentrate to meet the nutritional demands of early to mid lactation cows (Ryan, 1998), which is in contrast to the grass-based production system common for spring-calving dairy herds (Dillon et al., 2005). Both ensiled forage and concentrate are high-cost alternatives to grazed grass (Finneran et al., 2012). To increase the profitability of winter milk production, the management of feed inputs should be closely examined, particularly concentrate feed input. As global cereal-based biofuel production and the cost of oil continue to increase, dairy producers face upward pressure on concentrate feed costs.

Increasing the concentrate feed input in diets based on grass silage (Agnew et al., 1996) and maize silage (Fitzgerald and Murphy, 1999) has a positive effect on milk production and BCS loss (Delaby et al., 2009), otherwise known as a response to concentrate (Bargo et al., 2003). However, animals respond differently to concentrate supplementation due to variation within the herd, which is caused by differences in stage of lactation, parity, and genotype (Horan et al., 2005).

It is common for dairy producers to supplement forage with concentrates based on the average require- 
ment of the herd, which is described as flat rate feeding in Gill and Kaushal (2000), as this strategy offers ease of management. Where flat rate feeding is practiced, all cows are offered the same amount of concentrate DM irrespective of individual cow's potential milk production, BW, or stage of lactation. Such an approach may supply excess nutrients to lower performing cows and restrict the nutrient intake of individuals with high milk yield potential (Coppock et al., 1972; Smith et al., 1978; Pecsok et al., 1992). An alternative and more complicated feeding strategy is to allocate concentrates based on individual cow requirements or potential milk yield, which is described as feeding to yield in Leaver (1988). The concept of feeding dairy cows to their yield potential is based on the positive curvilinear relationship that exists between milk production and concentrate input (Kellaway and Harrington, 2004). This relationship is influenced by the genetic merit of the cow (Ferris et al., 1999) and the quality of the basal diet offered (Taylor and Leaver, 1984a). However, concentrate feeding strategy was found to have no significant effect on daily milk yield in early to mid lactation when grass silage was offered to appetite over a period of 19 to $24 \mathrm{wk}$ in studies by Taylor and Leaver (1984b) and Moisey and Leaver (1985). Conversely, over a 5-wk study, cows in mid lactation had a modest increase in milk solids yield when concentrates were fed to yield using grazed lucerne and maize silage as the basal diet (García et al., 2007).

Limited information exists on the effect of concentrate allocation strategy when a highly digestible maize silage and grass silage mix is used as the base feed. A highly digestible base feed will reduce the overall milk production response to concentrate in a herd (Moisey and Leaver, 1985), as cows with low milk production potential can attain a larger proportion of the total required nutrient intake from forage. Previously, when feeding to yield was examined (Taylor and Leaver, 1984a), the milk production of the first $14 \mathrm{~d}$ of lactation was used as an indicator of milk production potential (Moisey and Leaver, 1985). Cows are prone to metabolic disease during this period (Drackley, 1999). The present study used the milk production from wk 3 and 4 of lactation to categorize the cows more accurately into the different milk yield subgroups. The hypothesis of the current experiment was that feeding cows based on their milk yield subgroup would increase milk production compared with feeding all cows the same level of concentrate regardless of milk yield. The objective of our study was to examine the effects of concentrate feeding strategy, using 2 concentrate feeding amounts, on feed intake, milk yield, and milk composition of housed, autumn-calving Holstein-Friesian cows offered a base feed mix of grass silage and maize silage.

\section{MATERIALS AND METHODS}

The study was carried out at Teagasc, Animal and Grassland Research and Innovation Centre, Moorepark, Fermoy, Co. Cork, Ireland $\left(52^{\circ} 16^{\prime} \mathrm{N}, 8^{\circ} 25^{\prime} \mathrm{W}\right)$.

\section{Animals and Experimental Design}

Two experiments were conducted between October 24, 2011, and January 8, 2012 (yr 1), and between October 20, 2012, and January 5, 2013 (yr 2). In both years cows remained in their respective treatments for 11 wk. In yr 1, 60 cows were included in the experiment, and, in yr 2, 48 cows were included. Within year, cows were blocked in groups of 4 based on (mean \pm SD) calving date (yr 1: September $13 \pm 20$ d, yr 2: September $13 \pm 13 \mathrm{~d}$ ), parity (yr 1: $2.2 \pm 1.72$, yr 2: $2.3 \pm 1.18$ ), and the average of wk 3 and 4 of lactation for milk yield (yr 1: $24.3 \pm 4.92 \mathrm{~kg}$, yr 2: $22.7 \pm 3.37$ $\mathrm{kg}$ ), milk fat (yr 1: $49.0 \pm 7.11 \mathrm{~g} / \mathrm{kg}$, yr $2: 44.8 \pm 6.23$ $\mathrm{g} / \mathrm{kg}$ ), milk protein (yr 1: $37.0 \pm 2.65 \mathrm{~g} / \mathrm{kg}$, yr 2: 33.6 $\pm 2.60 \mathrm{~g} / \mathrm{kg}$ ), milk lactose (yr 1: $45.9 \pm 1.42 \mathrm{~g} / \mathrm{kg}$, yr 2: $45.5 \pm 1.66 \mathrm{~g} / \mathrm{kg}), \mathrm{BW}(\mathrm{yr} 1: 534 \pm 71.4 \mathrm{~kg}$, yr 2 : $519 \pm 32.0 \mathrm{~kg}$ ), and BCS (yr 1: $3.12 \pm 0.228$, r 2: 2.94 $\pm 0.197)$. The study was a randomized block design with a $2 \times 2$ factorial arrangement of treatments. Cows were randomly assigned to each of the 4 treatments so 1 cow from each block was in each treatment. The treatment factors were 2 amounts of concentrate, high concentrate (Hi; mean herd daily concentrate feeding of $7.0 \mathrm{~kg}$ of $\mathrm{DM} / \mathrm{cow}$ ) or low concentrate (Lo; mean herd daily concentrate feeding of $4.0 \mathrm{~kg}$ of $\mathrm{DM} / \mathrm{cow})$, and 2 strategies of concentrate feeding, flat rate $(\mathbf{F R})$ or group-fed to yield (GFY). In the GFY treatments, the lowest-yielding cows (mean pre-experimental milk yield: $20.0 \pm 3.07 \mathrm{~kg}$ ) received $5.3 \mathrm{~kg}$ of DM of concentrate on the Hi treatment and $2.3 \mathrm{~kg}$ of DM of concentrate on the Lo treatment, the highest-yielding cows (mean pre-experimental milk yield: $26.9 \pm 3.25 \mathrm{~kg}$ ) received $8.7 \mathrm{~kg}$ of DM of concentrate on the Hi treatment and $5.7 \mathrm{~kg}$ of DM of concentrate on the Lo treatment, and the average-yielding cows (mean pre-experimental milk yield: $23.5 \pm 3.03 \mathrm{~kg}$ ) received the same amount of concentrate as the respective FR group (i.e., $7.0 \mathrm{~kg}$ of DM of concentrate on the Hi treatment and $4.0 \mathrm{~kg}$ of DM of concentrate on the Lo treatment; Table 1).

\section{Treatment Feeding and Management}

Cows on the Hi-FR and Hi-GFY treatments were housed as 1 group and were offered a base feed mix consisting of $44.5 \%$ grass silage, $42.0 \%$ maize silage, $11.5 \%$ soybean meal, and $2.0 \%$ molasses on a DM basis. The Hi treatment was offered $7.0 \mathrm{~kg}$ of DM of concentrate, 
Table 1. Mean concentrate feeding on high- and low-concentrate diets

\begin{tabular}{lcc}
\hline Item & $\begin{array}{c}\text { High concentrate } \\
(\mathrm{kg} \text { of } \mathrm{DM})\end{array}$ & $\begin{array}{c}\text { Low concentrate } \\
(\mathrm{kg} \text { of } \mathrm{DM})\end{array}$ \\
\hline Flat rate & 7.0 & 4.0 \\
High variable rate & 8.7 & 5.7 \\
Medium variable rate & 7.0 & 4.0 \\
Low variable rate & 5.3 & 2.3 \\
\hline
\end{tabular}

which included the soybean meal and molasses offered in the base feed mix and $5.1 \mathrm{~kg}$ of DM concentrate offered in the parlor. The Lo-FR and Lo-GFY treatments were housed as 1 group and were offered a base feed mix consisting of $44.5 \%$ grass silage, $40.0 \%$ maize silage, $13.5 \%$ soybean meal, and $2.0 \%$ molasses on a DM basis. The Lo treatment was offered $4.0 \mathrm{~kg}$ of DM of concentrate, which included the soybean meal and molasses offered in the base feed mix and $1.7 \mathrm{~kg}$ of DM concentrate offered in the parlor. The nutritive characteristics of the base feed mix are presented in Table 2 .

Both groups were loose housed indoors in cubicle accommodation. The base feed mix was offered ad libitum, allowing for $5 \%$ refusals, and was prepared and delivered using a horizontal forage mixer (Keenan, Borris, Co. Carlow, Ireland). The base feed mix was offered in door-controlled feed bins which were mounted on weigh cells that measured individual animal feed intakes (Griffith Elder and Company Ltd., Suffolk, UK). The Griffith Elder MealMaster system deducts the postfeeding fresh weight of the base feed in a feed bin (after a cow has finished eating from that bin) from the initial fresh weight of base feed in that bin (recorded immediately before a cow is given permission to eat). Individual fresh weight feed intake is then given as the sum of these differences for each day (Patton et al., 2007). Weigh cells were zeroed and refusals were removed from the feed bins every second day. The concentrate was allocated in the parlor using Dairymaster FeedRite automatic feeders (Dairymaster, Causeway, Co. Kerry, Ireland). The concentrate offered in the milking parlor contained $25.0 \%$ wheat, $15.0 \%$ soya hulls, $10.0 \%$ extracted rapeseed, $10.0 \%$ extracted

Table 2. Nutritive characteristics of the base feed mixes (grass silage, maize silage, soybean meal, and molasses) that were formulated for high- and low-concentrate treatments

\begin{tabular}{lcc}
\hline Item & $\begin{array}{c}\text { High } \\
\text { concentrate }\end{array}$ & $\begin{array}{c}\text { Low } \\
\text { concentrate }\end{array}$ \\
\hline DM $(\%)$ & 30.0 & 30.3 \\
Net energy ${ }^{1}(\mathrm{UFL} / \mathrm{kg}$ of DM) & 0.87 & 0.87 \\
CP (\% of DM) & 15.7 & 16.5 \\
Starch (\% of DM) & 11.1 & 10.7 \\
NDF (\% of DM) & 46.8 & 46.0 \\
\hline
\end{tabular}

${ }^{1} \mathrm{UFL}$ (unité fourragère lait) = net energy value (Jarrige, 1989). sunflower seed, $10.0 \%$ palm kernel expeller, $6.0 \%$ milk solids, $5.0 \%$ maize gluten feed, $5.0 \%$ citrus pulp, $5.0 \%$ soybean meal, $4.0 \%$ oat feed, $0.5 \%$ palm oil, $4.0 \%$ calcined magnesite, and $0.5 \%$ protected trace elements on a DM basis (Glanbia, Clonroche, Co. Wexford, Ireland).

\section{Pre-Experimental and Training Period}

Training cows to use the Griffith Elder MealMaster system took place over a 5 -d period at 3 wk before the estimated mean calving date. The prepartum group was offered $17 \mathrm{~kg}$ of grass DM daily, which was grazed in situ to a 3.5 - to $4.0-\mathrm{cm}$ target residual height; in addition, once calved, cows were allocated $2.5 \mathrm{~kg}$ of DM of concentrate, which was increased to $4.3 \mathrm{~kg}$ of DM during the second week of lactation. Cows were housed full time $1 \mathrm{wk}$ before the start of the experiment and were offered a 50:50 grass silage:maize silage forage mix (formulated on a DM basis) with $2.6 \mathrm{~kg}$ of DM of soybean meal and $2.5 \mathrm{~kg}$ of DM of the experimental concentrate until assigned to their experimental treatments.

\section{Animal Measurements}

DMI. Samples of maize silage, grass silage, and soybean meal were collected twice per week and a sample of concentrate was collected once per week. The DM of the feed ingredient samples were used to formulate the base feed mix and to calculate the total dry matter intake (TDMI) from the fresh weight intakes recorded by the Griffith Elder MealMaster system.

Milk Yield and Composition. Individual cow milk yield $(\mathrm{kg})$ was recorded automatically at each morning $(0730 \mathrm{~h})$ and evening $(1530 \mathrm{~h})$ milking (Dairymaster). Milk fat, protein, and lactose concentrations were determined once weekly from the mean concentrations in an individual cow's successive evening and morning milk samples using a Milkoscan 203 (Foss Electric, Hillerød, Denmark; AOAC International, 1995; method 972.16).

$\boldsymbol{B} \boldsymbol{W}$ and $\boldsymbol{B} \boldsymbol{C S}$. Body weight was recorded once weekly using a portable weighing scale and Winweigh software package (Tru-test Limited, Auckland, New Zealand). During weighing, BCS was assessed weekly by the same experienced, trained observer using a 1- to 5 -scale $(1=$ emaciated, $5=$ extremely fat $)$ with 0.25 increments (Edmonson et al., 1989). Body weight and BCS change were calculated as the difference in BW and BCS (over $60 \mathrm{~d}$ ) from the start (average of first 2 wk) to the end (average of final 2 wk) of the study.

Blood Metabolites. Blood samples were collected on a fortnightly basis from the first week of the experimental period until the end of the experimental period. The samples were taken immediately after morning milking by venipuncture of the median coc- 
cygeal blood vessel on the ventral aspect of the tail. Blood samples were collected in 10-mL lithium heparin vacutainers (Becton Dickson, Plymouth, UK) and were refrigerated immediately after collection. The samples were centrifuged within $2 \mathrm{~h}$ of collection using a swing head centrifuge (Sigma Laborzentrifugen, Osterode am Harz, Germany) set to $3,000 \times g$ for $15 \mathrm{~min}$ at $5^{\circ} \mathrm{C}$. The plasma was decanted into two $1.5-\mathrm{mL}$ aliquots. These were labeled and stored at $-20^{\circ} \mathrm{C}$ until analysis.

Blood samples were analyzed for the metabolites glucose, NEFA, BHBA, and urea by enzymatic colorimetry using suitable kits (BHBA, urea, and glucose kits were supplied by ABX Mira, Montpellier, France; NEFA kits were supplied by Wako Chemicals, GmbH, Neuss, Germany) and an ABX Pentra auto analyzer (ABX Mira).

Chemical Analysis. Dry matter was measured by drying samples of feed ingredients at $90^{\circ} \mathrm{C}$ for 15 h (Beecher et al., 2013) in a forced-draft oven (Carbolite, Derbyshire, UK). The grass silage, concentrate, and soybean meal samples were analyzed fresh by near infrared reflectance spectroscopy (model 6500, FossNIR) for CP, ash, dry matter digestibility (DMD), water-soluble carbohydrates, lactic acid, and NDF concentrations. Samples of concentrate were milled and passed through a 1.0-mm screen before near infrared reflectance spectroscopy analysis. Maize silage samples were analyzed by wet chemistry for CP, NDF, ADF, ash, and starch. The $\mathrm{N}$ concentration was determined using a Leco FP428 N analyzer (Leco Australia Pty Ltd., Castle Hill, New South Wales, Australia; AOAC International, 1995; method 900.03) with a method adapted by Sweeney (1989). Crude protein was then determined as $\mathrm{N}$ concentration $\times 6.25$. Neutral detergent fiber was analyzed using the Ankom Fiber Analyzer (Ankom Technology Corporation, Macedon, NY; AOAC International, 1995; method 2002.04) using the procedure of Van Soest et al. (1991). Ash concentration was determined by placing samples in a muffle furnace for $16 \mathrm{~h}$ at $500^{\circ} \mathrm{C}$. Starch concentration was analyzed by treating the sample with hot diluted hydrochloric acid. Following filtration and clarification, the optical rotation of the prepared solution was measured using an automatic polarimeter (Optical Activity Ltd., Ramsey, Cambridgeshire, UK).

Energy Balance. Energy balance was estimated as the difference between estimated net energy intake and the sum of net energy required for maintenance, milk production, and growth. The associative effects of adding concentrates to forage is a reduction in DM degradation, which makes the net energy value of the total diet less than the sum of energy intake from each ingredient (Jarrige, 1989). To account for this, a correction factor for the negative associative effects of concentrate on DM degradation was also added to energy demand. Net energy intake was calculated using data collected from the Griffith Elder MealMaster, the DM proportions of each feed ingredient and the net energy (UFL; unité fourragère lait) value (Jarrige, 1989), which was assigned to each feed ingredient based on the feed ingredient chemical composition. Energy values (UFL) for molasses were based on O'Mara (1996).

The following equations (Jarrige, 1989) were used to estimate energy requirement:

$$
\begin{gathered}
\text { Maintenance requirement: UFL/d }= \\
1.4+[0.6 \times(\mathrm{BW}, \mathrm{kg} / 100)]
\end{gathered}
$$

Milk production requirement: $\mathrm{UFL} / \mathrm{d}=$ $[(0.054 \times$ milk fat, $\%)+(0.031 \times$ milk protein, $\%)$ $+(0.028 \times$ milk lactose, $\%)-0.015] \times \mathrm{kg}$ of milk;

Growth of cows $<40$ mo old: UFL $/ \mathrm{d}=3.25$

$$
-(0.08 \times \text { age }, \mathrm{mo}) ; \text { and }
$$

Negative associative effect of concentrate on diet digestibility: UFL $/ \mathrm{d}=[6.3 \times$ (proportion of concentrate $\left.\left.^{2}\right)\right]+[0.002 \times($ net energy intake, $\left.\left.\mathrm{UFL}^{2}\right)\right]-[0.017 \times$ net energy intake, UFL $]$.

\section{Statistical Analysis}

All statistical analysis was carried out using the mixed procedure of SAS (SAS Institute, 2011). The following model was used to analyze BCS and BW change:

$$
Y_{i j}=\mu+A_{i}+C_{j}+\mathrm{A}_{i} \times \mathrm{C}_{j}+T_{l}+b_{2} \mathrm{DIM}_{i}+e_{i j l},
$$

where $Y=$ the response variable for the $i$ th and the $j$ th treatment; $\mu=$ mean; $A i=$ concentrate feeding amount $(i=$ Hi or Lo $) ; C_{j}=$ concentrate feeding strategy $(j$ $=\mathrm{FR}$ or $\mathrm{GFY}) ; A_{i} \times C_{j}=$ the interaction between concentrate feeding amount and concentrate feeding strategy; $T_{l}=$ yr 1 or $2 ; b_{2} \mathrm{DIM}_{i j k}=\mathrm{DIM}$; and $e_{i j l}=$ residual error term.

Average daily milk yield, weekly milk composition, BW, BCS, feed intake, energy balance data, and fortnightly blood metabolites were analyzed using the model:

$$
\begin{aligned}
Y_{i j k}= & +A_{i}+C_{j}+A_{i} \times C_{j}+C_{j} \times W_{k}+W_{k} \\
& +T_{l}+b_{m} X_{i j k}+b_{2} \mathrm{DIM}_{i j k}+e_{i j k l m},
\end{aligned}
$$


Table 3. Mean ( $\pm \mathrm{SD})$ nutritive values of feed ingredients offered to all treatments in yr 1 and 2

\begin{tabular}{lccccc}
\hline Item & $\begin{array}{c}\text { Grass } \\
\text { silage }\end{array}$ & $\begin{array}{c}\text { Maize } \\
\text { silage }\end{array}$ & Concentrate & $\begin{array}{c}\text { Soybean } \\
\text { meal }\end{array}$ & Molasses $^{1}$ \\
\hline $\mathrm{DM}(\%)$ & $21.1 \pm 3.59$ & $26.9 \pm 3.11$ & $85.9 \pm 1.34$ & $86.8 \pm 1.06$ & 73.7 \\
$\mathrm{CP}(\%$ of DM) & $13.9 \pm 1.47$ & $8.6 \pm 1.74$ & $18.7 \pm 1.56$ & $47.3 \pm 1.67$ & 5.6 \\
$\mathrm{NDF}(\%$ of DM) & $40.9 \pm 4.95$ & $51.4 \pm 1.45$ & $22.7 \pm 23.1$ & $5.2 \pm 1.94$ & $\mathrm{NA}$ \\
Starch (\% of DM) & $\mathrm{NA}^{2}$ & $22.2 \pm 2.71$ & $19.2 \pm 4.74$ & $9.4 \pm 0.67$ & 140 \\
Ash (\% of DM) & $26.3 \pm 1.02$ & $4.7 \pm 0.10$ & $7.1 \pm 0.63$ & $5.1 \pm 0.47$ & $\mathrm{NA}$ \\
DM digestibility & $76.0 \pm 3.00$ & $\mathrm{NA}$ & $\mathrm{NA}$ & $\mathrm{NA}$ & $\mathrm{NA}$ \\
OM digestibility $_{\text {Net energy }}$ (UFL/kg of DM) & $\mathrm{NA}$ & $69.8 \pm 1.55$ & $\mathrm{NA}$ & $86.5 \pm 0.51$ & 83.0 \\
\hline
\end{tabular}

${ }^{1}$ Table values from Sauvant et al. (2004).

${ }^{2}$ Not available.

${ }^{3} \mathrm{UFL}$ (unité fourragère lait) = net energy value (Jarrige, 1989).

${ }^{4}$ Table values from Jarrige (1989).

where the variables are as explained previously. The model included experimental week (1-11) as the repeated measure denoted by $W_{k} ; C_{j} \times W_{k}=$ the interaction between concentrate feeding amount and experimental week; $b_{m} X_{i j k}=$ the respective pre-experimental variable; $b_{2} \mathrm{DIM}_{i j k}=$ DIM. The model also included model terms for subject (cow compressed with parity), autoregressive heterogeneous covariance structure, and block as the random effect. When no significant interaction between concentrate feeding amount and concentrate feeding strategy was found, the term was removed from the model.

\section{RESULTS}

\section{Chemical Analysis}

The chemical composition of the feeds is described in Table 3. The grass silage had a high DMD of $76.0 \%$ and CP $13.9 \%$. The maize silage and grass silage had similar energy concentrations of $0.86 \mathrm{UFL} / \mathrm{kg}$ of DM. The CP concentration of the soybean meal was as expected at
47.3\%. The CP concentration of the concentrate offered was $18.7 \%$ and it had an NDF concentration of $22.7 \%$ $\mathrm{DM}$ and a net energy value of $1.05 \mathrm{UFL} / \mathrm{kg}$ of DM.

\section{Animal Production}

DMI. No interaction was noted between concentrate feeding amount and feeding strategy on TDMI or the DMI of base feed mix. The Hi cows consumed $5.1 \mathrm{~kg}$ of DM of concentrate in the parlor, and approximately 1.6 $\mathrm{kg}$ of DM of soybean meal and $0.3 \mathrm{~kg}$ of DM of molasses in the base feed mix. The Lo cows consumed $1.7 \mathrm{~kg}$ of $\mathrm{DM}$ of concentrate in the parlor, and approximately 1.9 $\mathrm{kg}$ of DM of soybean meal and $0.3 \mathrm{~kg}$ of DM of molasses in the base feed mix. The TDMI of the Hi cows (18.7 $\mathrm{kg} /$ cow per day) was $2.9 \mathrm{~kg} /$ cow higher $(P<0.001)$ than the TDMI of the Lo cows (Table 4 ). The base feed mix intake of cows on the Hi treatment was $0.5 \mathrm{~kg} / \mathrm{cow}$ per day lower than the cows on the Lo treatment. Cows on the Hi treatment consumed a diet had a lower $(P$ $<0.001)$ proportion of forage and higher proportion of concentrate than cows on the Lo treatment. The dietary

Table 4. The effect of concentrate feeding strategy and feeding amount on daily DMI and energy balance

\begin{tabular}{|c|c|c|c|c|c|c|c|c|}
\hline \multirow[b]{2}{*}{ Item } & \multicolumn{4}{|c|}{ Treatment $^{1}$} & \multirow[b]{2}{*}{ SEM } & \multicolumn{3}{|c|}{ Significance } \\
\hline & Hi-FR & Hi-GFY & Lo-FR & Lo-GFY & & Amount & Strategy & Interaction \\
\hline Total DMI (kg of DM) & $18.6^{\mathrm{x}}$ & $18.9^{\mathrm{x}}$ & $15.7^{\mathrm{y}}$ & $15.9^{\mathrm{y}}$ & 0.36 & $<0.01$ & 0.36 & 0.94 \\
\hline Base feed mix intake ( $\mathrm{kg}$ of $\mathrm{DM}$ ) & $13.8^{\mathrm{x}}$ & $13.7^{\mathrm{x}}$ & $13.9^{\mathrm{y}}$ & $14.5^{\mathrm{y}}$ & 0.35 & 0.03 & 0.29 & 0.14 \\
\hline Forage proportion $(\%)$ & $62.6^{\mathrm{x}}$ & $62.7^{\mathrm{x}}$ & $74.7^{\mathrm{y}}$ & $75.5^{\mathrm{y}}$ & 0.85 & $<0.01$ & 0.48 & 0.49 \\
\hline Net energy requirement ${ }^{2}$ (UFL) & $18.0^{\mathrm{x}}$ & $17.9^{\mathrm{x}}$ & $16.6^{\mathrm{y}}$ & $17.0^{\mathrm{y}}$ & 0.38 & $<0.01$ & 0.33 & 0.32 \\
\hline Net energy intake (UFL) & $17.5^{\mathrm{x}}$ & $17.7^{\mathrm{x}}$ & $14.8^{\mathrm{y}}$ & $15.0^{\mathrm{y}}$ & 0.33 & $<0.01$ & 0.96 & 0.32 \\
\hline Net energy balance (UFL) & $-0.4^{\mathrm{x}}$ & $-0.5^{\mathrm{x}}$ & $-1.8^{\mathrm{y}}$ & $-2.1^{\mathrm{y}}$ & 0.28 & $<0.01$ & 0.33 & 0.57 \\
\hline OM intake ( $\%$ of DMI) & $88.6^{\mathrm{x}}$ & $88.9^{\mathrm{x}}$ & $87.7^{\mathrm{y}}$ & $87.7^{\mathrm{y}}$ & 0.14 & $<0.01$ & 0.76 & 0.49 \\
\hline NDF intake ( $\%$ of DMI) & $35.6^{\mathrm{x}}$ & $35.8^{\mathrm{x}}$ & $40.1^{\mathrm{y}}$ & $40.3^{y}$ & 0.35 & $<0.01$ & 0.20 & 0.83 \\
\hline CP intake (\% of DMI) & $17.3^{\mathrm{x}}$ & $17.4^{\mathrm{x}}$ & $17.6^{\mathrm{y}}$ & $17.6^{\mathrm{y}}$ & 0.06 & $<0.01$ & 0.76 & 0.88 \\
\hline
\end{tabular}

${ }_{\mathrm{x}, \mathrm{y}}$ Within a row means with different superscripts differ significantly $(P<0.05)$.

${ }^{1} \mathrm{Hi}-\mathrm{FR}=$ high-concentrate flate rate feeding; Hi-GFY = high-concentrate group-fed to yield feeding; Lo-FR = low-concentrate flat rate feeding; Lo-GFY = low-concentrate group-fed to yield feeding.

UFL (unité fourragère lait) = net energy value (Jarrige, 1989). 
Table 5. The effect of concentrate feeding strategy and feeding amount on milk production, milk composition, BW change, and BCS change

\begin{tabular}{|c|c|c|c|c|c|c|c|c|}
\hline Item & \multicolumn{4}{|c|}{ Treatment $^{1}$} & SEM & \multicolumn{3}{|c|}{ Significance } \\
\hline Milk yield $(\mathrm{kg})$ & $25.2^{\mathrm{x}}$ & $25.1^{\mathrm{x}}$ & $23.3^{\mathrm{y}}$ & $24.3^{\mathrm{y}}$ & 0.31 & $<0.01$ & 0.21 & 0.08 \\
\hline Milk protein (\%) & 3.35 & 3.34 & 3.30 & 3.32 & 0.031 & 0.12 & 0.95 & 0.48 \\
\hline Milk fat yield (kg) & $1.11^{\mathrm{x}}$ & $1.07^{\mathrm{x}}$ & $1.01^{\mathrm{y}}$ & $1.07^{\mathrm{x}}$ & 0.037 & 0.01 & 0.37 & 0.02 \\
\hline Milk protein yield $(\mathrm{kg})$ & 0.85 & 0.82 & 0.78 & 0.81 & 0.026 & 0.97 & 0.22 & 0.11 \\
\hline
\end{tabular}

${ }^{\mathrm{x}, \mathrm{y}}$ Within a row means with different superscripts differ significantly $(P<0.05)$.

${ }^{1} \mathrm{Hi}-\mathrm{FR}=$ high-concentrate flate rate feeding; Hi-GFY = high-concentrate group-fed to yield feeding; Lo-FR = low-concentrate flat rate feeding; Lo-GFY $=$ low-concentrate group-fed to yield feeding.

proportions of $\mathrm{OM}$ and $\mathrm{CP}$ were similar between the $\mathrm{Hi}$ and Lo treatments; however, the NDF proportion was $45 \mathrm{~g} / \mathrm{kg}$ of DMI higher $(P<0.001)$ on the Lo compared with the Hi treatment due to the higher proportion of forage and lower proportion of concentrate. The intake of the base feed mix, concentrate, and, consequently, TDMI was not different between the FR or GFY treatments.

Milk Yield. The milk yield of the Hi cows was $1.3 \mathrm{~kg}$ higher $(P<0.001)$ than the milk yield of cows on the Lo treatment (Table 5 ). The concentration of milk fat and protein was not significantly different between $\mathrm{Hi}$ and Lo treatments. The yield of milk fat was $0.05 \mathrm{~kg} /$ cow per day higher $(P<0.05)$ on the Hi treatment than on the Lo treatment as a result of increased milk yield. The interaction between concentrate feeding amount and feeding strategy for milk solids yield is illustrated in Table 5. The Lo-GFY treatment resulted in higher $(P<0.05)$ milk solids yield $(0.09 \mathrm{~kg} /$ cow per day $)$ than Lo-FR; but the Hi treatment had similar milk solids yield on both the FR and GFY treatments. No effect of concentrate feeding strategy on milk yield or milk composition was observed.

$\boldsymbol{B} \boldsymbol{W}$ and $\boldsymbol{B} \boldsymbol{C S}$. No effect of concentrate feeding amount or concentrate feeding strategy on BW change was noted. Cows on the Lo treatment lost more body condition $(P<0.05)$ than cows on the Hi treatment during the experiment (Table 5). In addition, FR cows had greater $(P<0.05)$ loss of body condition $(-0.10$ BCS units) than GFY cows.

Blood Metabolites. No effect of concentrate feeding amount on plasma glucose concentration was seen (Figure 2). Cows fed the Lo diet had higher NEFA (0.03 $\mathrm{mmol} / \mathrm{L})$ and urea $(0.57 \mathrm{mmol} / \mathrm{L})$ concentrations $(P$ $<0.001$ ) over the experimental period than those fed a Hi diet. The concentration of BHBA was $10 \mathrm{mmol} / \mathrm{L}$ higher $(P<0.001)$ on the Hi treatment than on the Lo treatment. Cows which were on the GFY treatment had a higher concentration of BHBA $(0.03 \mathrm{mmol} / \mathrm{L})$ than FR cows $(0.52 \mathrm{mmol} / \mathrm{L} ; P<0.01)$. No effect of concentrate feeding strategy was observed for plasma glucose, NEFA, or urea concentrations.

Energy Balance. Cows offered the Hi treatment had an increased $(P<0.001)$ energy requirement (1.2 UFL/cow per day) than cows on the Lo treatment (Table 4) as a result of increased milk solids yield (Table 5). Moreover, energy intake was $2.6 \mathrm{UFL} / \mathrm{cow}$ per day greater when cows were offered the Hi diet, as TDMI was $2.9 \mathrm{~kg} /$ cow per day higher on this treatment. Estimated energy balance during the experiment was negative in all treatments; however, cows on the Lo diet had an estimated negative energy balance that was $-1.9 \mathrm{UFL} /$ cow per day, and cows on the Hi diet had

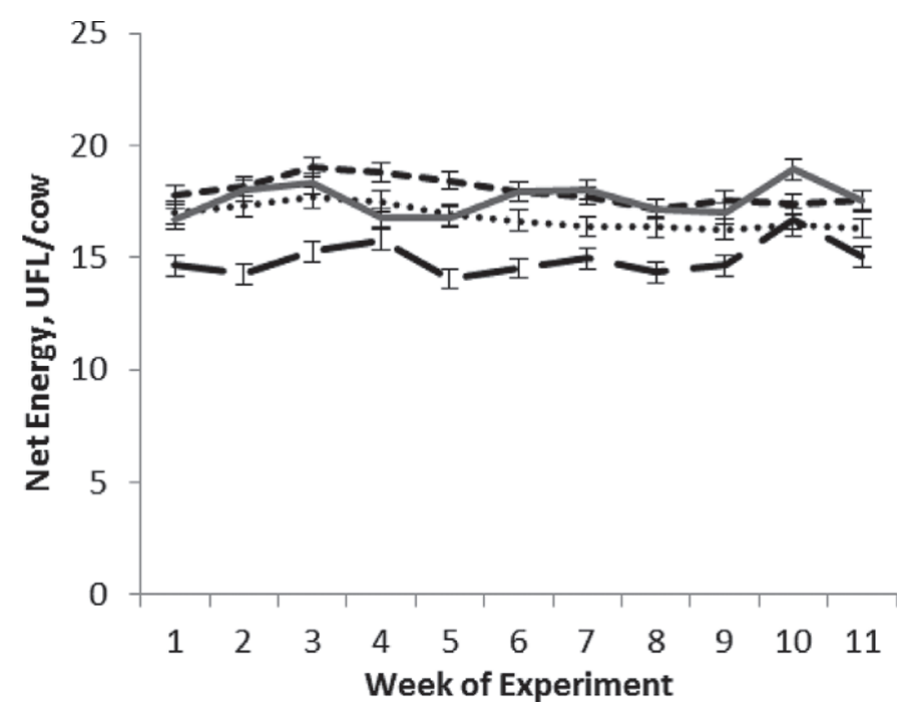

Figure 1. Net energy intake and requirement for high- and low-concentrate treatments during the experimental period. High-concentrate net energy requirement is denoted by a short dashed line (- - -); high-concentrate net energy intake is denoted by a solid line $(-)$; low-concentrate net energy requirement is denoted by a dotted line (...); low-concentrate net energy intake is denoted by a long dashed line $(--)$. Error bars represent the standard error of the mean. 
an estimated negative energy balance that was -0.5 $\mathrm{UFL} /$ cow per day $(P<0.001)$. Concentrate feeding strategy had no significant effect on energy requirement or energy intake and no effect on energy balance was noted (Figure 1).

\section{DISCUSSION}

The current study was undertaken to compare the effects of feeding high or low amounts of concentrate based on 2 concentrate-feeding strategies, offering a base feed mix consisting of grass silage, maize silage, soybean meal, and molasses. The hypothesis was that mean milk production would be increased by offering concentrate based on milk yield, particularly with high-concentrate diets. The hypothesis was rejected, as concentrate-feeding strategy had no effect on DMI and milk production; however, cows on the GFY treatment had a smaller reduction in BCS than cows on the FR treatment.

\section{Concentrate Feeding Amount}

Cows offered the Hi diet had a higher TDMI and energy intake than the cows offered a Lo diet, mainly due to the increase in concentrate intake. The substitution of base feed intake on the Hi treatment $(0.5 \mathrm{~kg}$ of $\mathrm{DM} /$ cow or $0.16 \mathrm{~kg}$ of forage $/ \mathrm{kg}$ of additional concentrate) compared with the Lo treatment was a result of increased over all energy intake, which was supplied by additional concentrate. Agnew et al. (1996) reported a reduction in forage intake $(0.6 \mathrm{~kg}$ of $\mathrm{DM} / \mathrm{cow})$ when cows were offered $6 \mathrm{~kg}$ of concentrate compared with 4 $\mathrm{kg}$ of concentrate on diets with similar forage to concentrate ratios as the present study. When high-quality forage was offered in a study by Ferris et al. (2001), the substitution of forage for concentrate (substitution rate) was $0.08 \mathrm{~kg}$ of forage $\mathrm{DM} / \mathrm{kg}$ of concentrate $\mathrm{DM}$ as the proportion of concentrate was increased from 10 to $30 \%$. The overall reduction in forage intake was 0.4 $\mathrm{kg}$, which is similar to the results of the present study. However, as the proportion of concentrate increased from 30 to $50 \%$, the substitution rate was $4.0 \mathrm{~kg}$ of DM $(0.87 \mathrm{~kg}$ of forage $\mathrm{DM} / \mathrm{kg}$ of concentrate DM). The substitution of forage with concentrate began to decrease as the proportion of concentrate was increased further from 50 to $70 \%$ of TDMI $(0.77 \mathrm{~kg}$ of forage DM $/ \mathrm{kg}$ of concentrate DM). This follows the curvilinear effect of concentrate input on both substitution of forage and response to concentrate (Kellaway and Harrington, 2004). The effects of substitution rate were decreased when low-quality forage was offered as the base diet, as the cows had a larger demand for concentrate supplementation (Ferris et al., 2001). Moreover, supplying a lower-quality base feed can increase the degree of negative energy balance (Fitzgerald et al., 1999) due to reduced energy intake. The substitution of forage for concentrate was low in the present experiment, as Hi cows were in negative energy balance (NEB) and reducing forage intake would further limit total energy intake (Faverdin et al., 1991).

The increase in energy intake on the Hi treatment reduced the degree of NEB, and increased daily milk yield compared with the Lo treatment. The result is similar to Moisey and Leaver (1985), who found that higher amounts of concentrate increased milk yield $(0.45 \mathrm{~kg}$ of milk $/ \mathrm{kg}$ of concentrate). The milk yield response to additional concentrate and substitution rate are closely linked (Bargo et al., 2002). Once concentrate is offered, the overall energy intake is increased at the expense of some forage, which results in a reduced milk yield response to concentrate (Gill and Kaushal, 2000). The current study used high-quality grass silage (76.0 DMD $\mathrm{g} / \mathrm{kg}$ of $\mathrm{DM} ; 0.86 \mathrm{UFL} / \mathrm{kg}$ of $\mathrm{DM}$ ) and maize silage (0.86 UFL/kg of DM) compared with that offered by Mayne and Gordon (1984), who found a higher response in milk yield to concentrate supplementation $(0.98 \mathrm{~kg}$ of milk $/ \mathrm{kg}$ of concentrate). The milk yield response to concentrate found by Ferris et al. (2002) was $0.6 \mathrm{~kg}$ of milk $/ \mathrm{kg}$ of concentrate DM, slightly higher than that found in the present study. Although, the basal feed in the study of Ferris et al. (2002) was lower in digestibility than the base feed used in the present study, the energy values of the 2 diets were similar. However, cows in the study of Ferris et al. (2002) were of higher genetic merit (milk yield of $31.8 \mathrm{~kg} / \mathrm{cow}$ per day) than cows included in the present study, which Ferris et al. (1999) reported would influence the response to additional concentrate feeding. Stage of lactation also has a large effect on the substitution rate and response to concentrate as the cow regulates her body fat reserves and the composition of milk changes (Leaver 1988). Where a large variation in calving date within a herd is observed more variation in response to concentrate may exist, which merits further investigation into the effects of feeding to yield. In the present study, however, cows were calved within a 6 -wk calving period.

In the present study, the milk fat and protein concentration were unaffected by the amount of concentrate, which is likely related to the proportion of concentrate being $247 \mathrm{~g} / \mathrm{kg}$ of DMI on the Lo diet and $373 \mathrm{~g} / \mathrm{kg}$ of DMI on the Hi diet. An increase in milk protein concentration and reduction in milk fat concentration was reported by Andersen et al. (2003) when concentrate allowance was increased from 250 to $750 \mathrm{~g} / \mathrm{kg}$ of DMI. Agnew et al. (1996) found that increasing the amount of concentrate from 280 to $480 \mathrm{~g} / \mathrm{kg}$ of DMI also resulted in an increase in milk protein concentra- 

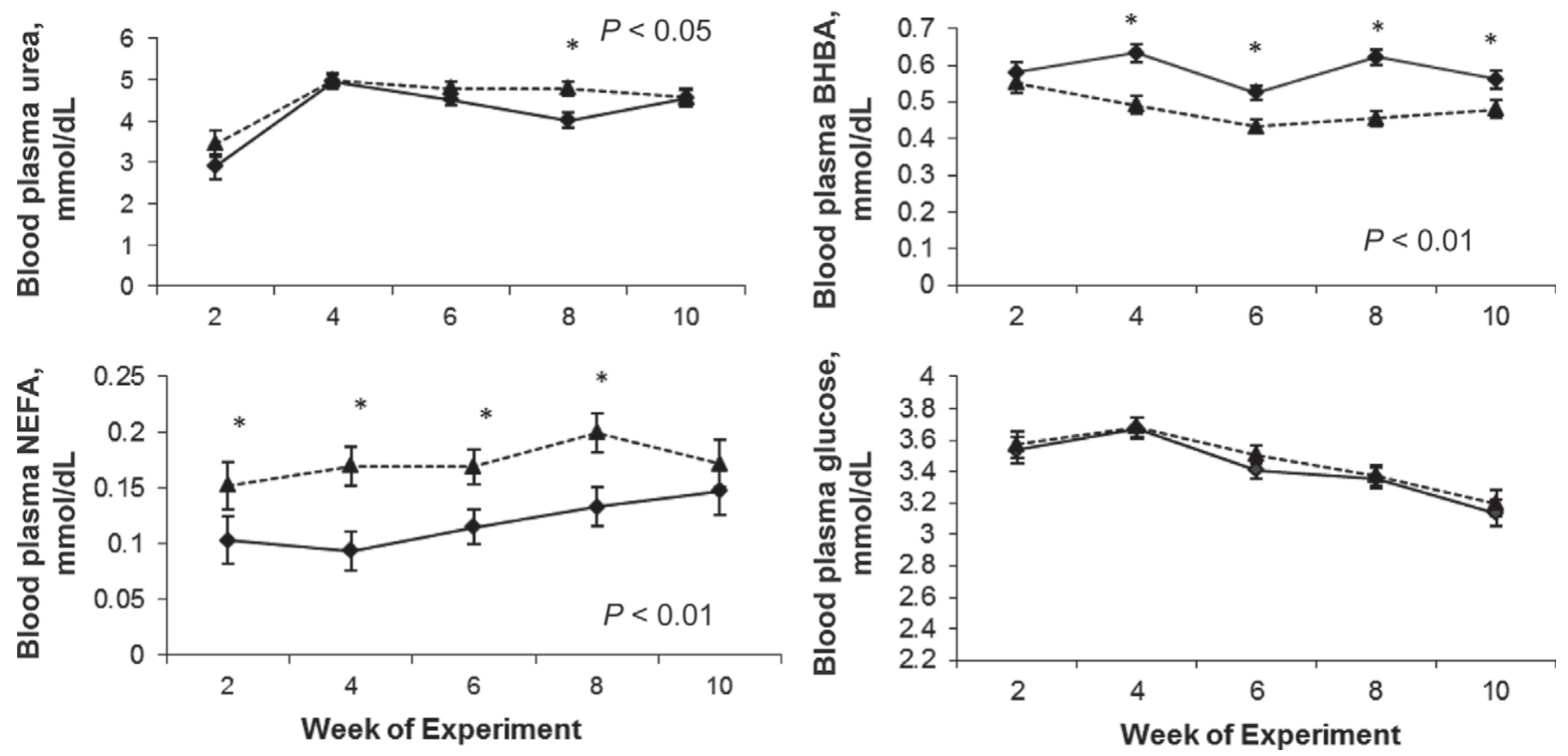

Figure 2. The effect of concentrate feeding amount on blood metabolite concentrations during the 11-wk experiment. High-concentrate treatment is denoted by a circle $(\mathbf{)})$; low-concentrate treatment is denoted by a triangle $(\boldsymbol{\Delta})$. The $P$-value indicates the effect of the concentrate feeding amount by time interaction; an asterisk $(*)$ indicates a significant difference between treatments during this experimental week. Error bars represent the standard error of the mean.

tion and a reduction in milk fat concentration. However, when the proportion of concentrate was increased from 280 to $380 \mathrm{~g}$ of concentrate $/ \mathrm{kg}$ of DMI there were no significant differences in milk protein or milk fat concentrations between diets. In the present study, the proportion of concentrate was $373 \mathrm{~g} / \mathrm{kg}$ of DMI on the Hi diet and $247 \mathrm{~g} / \mathrm{kg}$ of DMI on the Lo diet, and no significant difference in milk protein or fat concentrations were found. Both the $\mathrm{Hi}$ and Lo concentrate diets in the present study were formulated to have similar concentrations of $\mathrm{OM}$ and $\mathrm{CP}$. The concentration of NDF was above animal requirements in both the $\mathrm{Hi}(35.7 \%)$ and Lo (40.2\%) diets (NRC 2001), so no effect of diet on milk fat concentration was expected. The reduction in milk solids yield on the Lo-FR treatment compared with all other treatments was due to the significantly lower milk fat yield and numerically lower milk protein yield, which was largely driven by the reduced milk yield, as no significant difference in concentration was noted between treatments.

Concentrate feeding amount had no significant effect on live weight change. The results show, however, that cows on the Hi treatment mobilized less body reserves over the experimental period. Cows with higher energy intake are known to mobilize less body tissue in early lactation (Berry et al., 2006); however, even though BCS was reducing throughout the experimental period, mean BW was increasing. A similar trend was reported by Veerkamp et al. (1994). Previous studies have concluded that BW change is not a practical representation of tissue mobilization (Beever et al., 1998; Friggens et al., 1998; Ferris et al., 2002), but may indicate skeletal growth or gut fill. Growth of cows less than 40 mo old was considered in the energy balance estimation and contributed to the increase in BW during the present experiment.

Estimated energy balance suggested that, on both the high- and low-concentrate diets, the cows were in NEB. Cows offered the Hi diet were, however, in less $\mathrm{NEB}$, and may therefore have returned to a positive energy balance sooner than cows on the Lo treatment (Berry et al., 2006). In studies where increased concentrate allowance resulted in increased energy intake (Ferris et al., 2002; Reist et al., 2003), cows on the Hi treatment resumed positive energy balance sooner than those on the Lo treatment. The mobilization of fat reserves due to NEB has been correlated with a loss in BCS (Gallo et al., 1996), which was evident in the current experiment. This may also be indicated by the higher blood plasma NEFA concentrations on the Lo treatment. It is likely that the concentration of blood plasma NEFA was higher in the Lo treatment due to significantly lower feed intake (Nikkhah et al., 2008) and the resulting greater NEB. However, the concentra- 
tion of NEFA was within the normal range expected for bovine blood plasma (Nikkhah et al., 2008), indicating that the extent of BCS loss was not excessive.

The difference in the concentration of blood plasma urea and glucose between the Lo and Hi cows was not biologically significant, as both of the metabolites were within the normal range (Macrae et al., 2006) for all weeks of the experiment. This indicated that cows on all treatments were supplied with sufficient dietary protein throughout the experimental period (NRC, 2001) and were not deficient of carbohydrates.

Increased DMI results in increased VFA production in the rumen (Nikkhah et al., 2008). This will result in an increased butyrate transformation to BHBA across the rumen wall (Reynolds, 2002). In the current study, cows on the Hi treatment had a higher concentration of BHBA in the blood plasma than cows on the Lo treatment, which is likely the result of their greater overall DMI.

\section{Concentrate Feeding Strategy}

No effect of concentrate feeding strategy on TDMI, energy intake, and milk production was observed. Similarly, concentrate feeding strategy had no significant effect on energy demand or energy balance. These results correspond with the literature, as concentrate feeding strategy is considered to have no significant effect on milk production (Taylor and Leaver, 1984a; Moisey and Leaver, 1985).

The mean concentrate input on the FR treatment was the same as the mean concentrate input on the corresponding GFY treatment. Although no effect of concentrate feeding strategy on milk yield was noted, there was less variation in milk yield within a treatment when cows were offered concentrate at a FR (24.3 $\pm 4.1 \mathrm{~kg}$ on FR, and $24.7 \pm 5.4 \mathrm{~kg}$ on GFY), similar to the results of Moisey and Leaver (1985). Basing the mean concentrate allowance of the GFY treatment on the concentrate allowance of the FR treatment may have limited cows to the range of production exhibited on the FR treatment. Previous experiments (Taylor and Leaver 1984a; Moisey and Leaver 1985) found that feeding to yield had no significant effect on milk yield when the overall mean daily concentrate allocation of the feed to yield treatment was the same as the flat rate treatment using grass silage as the basal diet.

An increase in milk solids yield, as a result of feeding concentrates to yield, was reported by García et al. (2007) when cows were allocated a grazed lucerne and maize silage base forage. The results were based, however, on data collected over 3 consecutive weeks, for treatments which were applied between wk 11 and 16 of lactation. The results of experiments performed by Taylor and Leaver (1984a,b; 1986) and Moisey and Leaver (1985), were based on data collected over a 19- to 24-wk period from early lactation and reported no significant effect of concentrate feeding strategy on milk yield or milk solids yield when cows were allocated grass silage or hay as the base forage. Similarly, the present study was carried out over an 11-wk period and used cows in early to mid-lactation, and found that concentrate feeding strategy had no effect on milk yield or milk solids yield when cows were allocated maize silage and grass silage as the base forage.

Leaver (1988) concluded that a concentrate feeding strategy would have little effect on milk production unless forage input was restricted. The base feed mix in the current experiment was offered ad libitum, but cows remained in NEB on both the high- and low-concentrate treatments. Restricting the base feed mix in the current study may have increased the energy deficit, which will result a larger response to concentrate.

\section{CONCLUSIONS}

Our study has clearly shown that allocating concentrate based on milk yield in early lactation has no significant effect on milk production when compared with a simple FR feeding strategy. A simple FR feeding strategy may reduce the accuracy with which concentrate is offered to each individual cow; however, in our study, no reduction in milk production or energy balance was noted compared with GFY. The total quantity of concentrate included in the diet does, however, have a significant effect on milk production. By increasing the total amount of concentrate offered, cows had higher TDMI and energy intake, which resulted in increased milk production and reduced NEB and BCS loss.

\section{ACKNOWLEDGMENTS}

The authors appreciate the input of J. P. Murphy from Teagasc Animal and Grassland Research and Innovation Centre (Moorepark, Co. Cork, Ireland) and all Moorepark farm staff for their technical assistance and care of the experimental cows during the study. The authors also thank D. Berry and S. Butler from Teagasc Moorepark and J. Grant from Teagasc Food Research Centre (Ashtown, Dublin, Ireland) for their advice and input in the statistical analysis.

\section{REFERENCES}

Agnew, K. W., C. S. Mayne, and J. G. Doherty. 1996. An examination of the effect of method and level of concentrate feeding on milk production in dairy cows offered a grass silage-based diet. Anim. Sci. $63: 21-31$.

Andersen, J. B., N. C. Friggens, K. Sejrsen, M. T. Sørensen, L. Munksgaard, and K. L. Ingvartsen. 2003. The effects of low vs. high 
concentrate level in the diet on performance in cows milked two or three times daily in early lactation. Livest. Prod. Sci. 81:119-128.

AOAC International. 1995. Official Methods of Analysis. 16th ed. AOAC International, Washington, DC.

Bargo, F., L. D. Muller, J. E. Delahoy, and T. W. Cassidy. 2002. Milk response to concentrate supplementation of high producing dairy cows grazing at two pasture allowances. J. Dairy Sci. 85:17771792 .

Bargo, F., L. D. Muller, E. S. Kolver, and J. E. Delahoy. 2003. Invited review: Production and digestion of supplemented dairy cows on pasture. J. Dairy Sci. 86:1-42.

Beecher, M., D. Hennessy, T. M. Boland, M. O'Donovan, and E. Lewis. 2013. Comparing drying protocols for perennial ryegrass samples in preparation for chemical analysis. Pages 239-242 in 22nd Int. Grassl. Congr., Sydney, Australia. New South Wales Department of Primary Industry, New South Wales, Australia.

Beever, D. E., S. B. Cammell, J. D. Sutton, N. Rowe, and G. E. Perrott. 1998. Energy metabolism in high yielding dairy cows. Page 13 in Proc. Br. Soc. Anim. Sci. Mtg. British Society of Animal Science, Scarborough, UK.

Berry, D. P., R. F. Veerkamp, and P. Dillon. 2006. Phenotypic profiles for body weight, body condition score, energy intake, and energy balance across different parities and concentrate feeding levels. Livest. Sci. 104:1-12

Coppock, C. E., C. H. Noller, B. W. Crowl, C. D. McLellon, and C. L. Rhykerd. 1972. Effect of group versus individual feeding of complete rations on feed intake of lactating cows. J. Dairy Sci. 55:325-327.

Delaby, L., P. Faverdin, G. Michel, C. Disenhaus, and J. L. Peyraud. 2009. Effect of different feeding strategies on lactation performance of Holstein and Normande dairy cows. Animal 3:891-905.

Dillon, P., J. R. Roche, L. Shalloo, and B. Horan. 2005. Optimising financial return from grazing in temperate pastures. Page 131-147 in Utilisation of Grazed Grass in Temperate Animal Systems: 20th Int. Grassl. Congr., Cork, Ireland.

Drackley, J. K. 1999. Biology of dairy cows during the transition period: The final frontier? J. Dairy Sci. 82:2259-2273.

Edmonson, A. J., I. J. Lean, L. D. Weaver, T. Farver, and G. Webster. 1989. A body condition scoring chart for Holstein dairy cows. J. Dairy Sci. 72:68-78.

Faverdin, P., J. P. Dulphy, J. B. Coulon, R. Vérité, J. P. Garel, J. Rouel, and B. Marquis. 1991. Substitution of roughage by concentrates for dairy cows. Livsest. Prod. Sci. 27:137-156.

Ferris, C. P., F. J. Gordon, D. C. Patterson, D. J. Kilpatrick, C. S. Mayne, and M. A. McCoy. 2001. The response of dairy cow of high genetic merit to increasing proportion of concentrate in the diet with high and medium quality silage. J. Agric. Sci. 136:319-329.

Ferris, C. P., F. J. Gordon, D. C. Patterson, C. S. Mayne, and D. J. Kilpatrick. 1999. The influence of dairy cow genetic merit on the direct and residual response to level of concentrate supplementation. J. Agric. Sci. 132:467-481.

Ferris, C. P., M. A. McCoy, S. D. Lennox, D. C. Catney, and F. J. Gordon. 2002. Nutrient utilisation and energy balance associated with two contrasting winter milk production systems for high genetic merit autumn calving dairy cows. Ir. J. Agric. Food Res. 41:55-70.

Finneran, E., P. Crosson, P. O'Kiely, L. Shalloo, D. Forristal, and M. Wallace. 2012. Stochastic simulation of the cost of home-produced feeds for ruminant livestock systems. J. Agric. Sci. 150:123-139.

Fitzgerald, J. J., and J. J. Murphy. 1999. A comparison of low starch maize silage and grass silage and the effect of concentrate supplementation of the forages or inclusion of maize grain with the maize silage on milk production by dairy cows. Livest. Prod. Sci. 57:95-111.

Friggens, N. C., G. C. Emmans, I. Kyriazakis, J. D. Oldham, and M. Lewis. 1998. Feed intake relative to stage of lactation for dairy cows consuming total mixed diets with a high or low ratio of concentrate to forage. J. Dairy Sci. 81:2228-2239.

Gallo, L., P. Carnier, M. Cassandro, R. Mantovani, L. Bailoni, B. Contiero, and G. Bittante. 1996. Change in body condition score of Holstein cows as affected by parity and mature equivalent milk vield. J. Dairy Sci. 79:1009-1015.

García, S. C., M. Pedernera, W. J. Fulkerson, A. Horadagoda, and K. Nandra. 2007. Feeding concentrates based on individual cow requirements improves the yield of milk solids in dairy cows grazing restricted pasture. Aust. J. Exp. Agric. 47:502.

Gill, M., and J. Kaushal. 2000. Feeding of grass silage to dairy cows with special reference to systems of concentrate feeding in United Kingdom: A review. Ag. Rev.-Ag. Res. Commun. Cent. India 21:71-79

Horan, B., P. Dillon, D. P. Berry, P. O'Connor, and M. Rath. 2005. The effect of strain of Holstein-Friesian, feeding system and parity on lactation curves characteristics of spring-calving dairy cows. Livest. Prod. Sci. 95:231-241.

Jarrige, R. 1989. Ruminant Nutrition: Recommended Allowances and Feed Tables. Institut National de la Recherche Agronomique, Paris, France.

Kellaway, R., and T. Harrington. 2004. Feeding Concentrates: Supplements for Dairy Cows. CSIRO Publishing, Victoria, Australia.

Leaver, D. 1988. Level and pattern of concentrate allocation to dairy cows. Pages 315-326 in Nutrition and Lactation in the Dairy Cow. P. C. Garnsworthy, ed. Butterworths, Essex, UK.

Macrae, A. L., D. Whitaker, E. Burrough, A. Dowell, and J. Kelly. 2006. Use of metabolic profiles for the assessment of dietary adequacy in UK dairy herds. Vet. Rec. 159:655-661.

Mayne, C. S., and F. J. Gordon. 1984. The effect of type of concentrate and level of concentrate feeding on milk production. Anim. Sci. 39:65-76.

Moisey, F. R., and J. D. Leaver. 1985. Systems of concentrate allocation for dairy cattle 3 . A comparison of two flat-rate feeding systems at two amounts of concentrates. Anim. Sci. 40:209-217.

NRC. 2001. Nutrient Requirements of Dairy Cattle. 7th rev. ed. Natl. Acad. Press, Washington, DC.

Nikkhah, A., C. J. Furedi, A. D. Kennedy, G. H. Crow, and J. C. Plaizier. 2008. Effects of feed delivery time on feed intake, milk production, and blood metabolites of dairy cows. J. Dairy Sci. 91:4249-4260.

O'Mara, F. 1996. A net energy system for cattle and sheep. Pages 5-21 in A Net Energy System for Cattle and Sheep. Department of Animal Science and Production, University College Dublin, Ireland.

Patton, J., D. Kenny, S. McNamara, J. Mee, F. O'mara, M. Diskin and J. Murphy. 2007. Relationships among milk production, energy balance, plasma analytes, and reproduction in Holstein-Friesian cows. J. Dairy Sci. 90:649-658.

Pecsok, S. R., M. McGilliard, R. James, T. Johnson, and J. Holter. 1992. Estimating production benefits through simulation of group and individual feeding of dairy cows. J. Dairy Sci. 75:1604-1615.

Reist, M., D. Erdin, D. Von Euw, K. Tschuemperlin, H. Leuenberger, C. Delavaud, Y. Chilliard, H. M. Hammon, N. Kuenzi, and J. W. Blum. 2003. Concentrate feeding strategy in lactating dairy cows: Metabolic and endocrine changes with emphasis on leptin. J. Dairy Sci. 86:1690-1706.

Reynolds, C. 2002. Economics of visceral energy metabolism in ruminants: Toll keeping or internal revenue service? J. Anim. Sci. 80:74-84.

Ryan, G. 1998. Strategies for the feeding and management of dairy cows for both seasonal and non-seasonal milk production systems in Ireland. Thesis. Agriculture and Vet. Med, University College Dublin, Ireland.

SAS Institute. 2011 SAS 9. 3 Output Delivery System: User's Guide. SAS Institute Inc., Cary, NC.

Sauvant, D., J. M. Perez, and G. Tran. 2004. Molasses-Sugarcane. Pages 238-239 in Tables of Composition and Nutritional Value of Feed Materials, Pigs, Poultry, Cattle, Sheep, Goats, Rabbits, Horses, Fish. Wageningen Acedimic Publishers, Wageningen, The Neatherlands.

Smith, N. E., G. R. Ufford, C. E. Coppock, and W. G. Merrill. 1978. One group versus two group system for lactating cows fed complete rations. J. Dairy Sci. 61:1138-1145. 
Sweeney, R. A. 1989. Generic combustion method for determination of crude protein in feeds: Collaborative study. J. Assoc. Off. Anal. Chem. 72:770-774.

Taylor, W., and J. D. Leaver. 1984a. Systems of concentrate allocation for dairy cattle 2. A comparison of two patterns of allocation for autumn-calving cows offered two qualities of grass silage ad libitum. Anim. Sci. 39:325-333.

Taylor, W., and J. D. Leaver. 1984b. Systems of concentrate allocation for dairy cattle 1 . A comparison of three patterns of allocation for autumn-calving cows and heifers offered grass silage ad libitum. Anim. Sci. 39:315-324.
Taylor, W., and J. D. Leaver. 1986. Systems of concentrate allocation for dairy cattle. 4. A comparison of two amounts and two patterns of allocation. Anim. Sci. 43:17-26.

Van Soest, P. J., J. B. Robertson, and B. A. Lewis. 1991. Methods for dietary fiber, neutral detergent fiber, and nonstarch polysaccharides in relation to animal nutrition. J. Dairy Sci. 74:3583-3597.

Veerkamp, R. F., G. Simm, and J. D. Oldham. 1994. Effects of interaction between genotype and feeding system on milk production, feed intake, efficiency and body tissue mobilization in dairy cows. Livest. Prod. Sci. 39:229-241. 